pdf Retrieved from https://khm.gov.ua/sites/default/files/CityProgramms/informaciya_pro_vykonannya_programy_za_i-e_ pivrichchya_2019_roku_29.pdf [in Ukrainian].

6. V.B. Samoilenko, N.P. Yakovenko, I.O. Petriashev (2018). Medytsyna i sotsialna reabilitatsiia: pidruchnyk - 2-e vyd., pererobl. i dopov. Kyiv : VSV «Medytsyna» [in Ukrainian].

7. S.S. Sapunkova, L.O. Pits, A.F. Hutnitska (2018). Medychna ta sotsialna reabilitatsiia: navch.-metod. posib. Kyiv : VSV «Medytsyna» [in Ukrainian].

8. Romanovska L.I., Dzhyhun L.M., Syniuk N.V. (2009). Teoriia ta praktyka reabilitatsiinoi roboty: navch. posibnyk. Khmelnytskyi: KhNU [in Ukrainian].

9. Sait naukovo-praktychnoho tsentru «Tekhnolohii neiroreabilitatsii» [Site of the Scientific and Practical Center «Neurorehabilitation Technologies»]. http://rehabtraining.org.ua. Retrieved from http://rehabtraining.org.ua/8-articles/115-fizichna-terapiya [in Ukrainian].

Bryndikov Yu. L. Concept of the purpose of the functioning of the complex rehabilitation center and assistance to the participants of the military actions on the basis of the Khmelnitsky National University

Military actions in the east of Ukraine have led to a deep socio-economic crisis in the country, worsened such difficult situation of socially vulnerable groups of people, provoked the emergence of a separate category of people who got into difficult life circumstances - servicemen-participants of hostilities.

The fighting is complicated by emotional and physical stressors, which often leads to the disadaptation of military personnel. Combatants' physical and psychological reserves are minimized, leading to disorders, stress and post-traumatic stress disorder (PTSD).

A considerable number of military personnel who took part in the fighting require a lot of attention and organization of complex rehabilitation, which involves a combination of the following components: social (restoration of human health, its social status lost due to problems that led to difficult situation), psychological (restoration of lost personality abilities to interact with the environment), legal (restoration / acquisition of legal rights of the combatant), medical / physical (prevention of disability at the expense of innovations of impaired functions and efficiency) and pedagogical (restoration of spiritual state, personality integrity). Together with the liberators, their families, representing a separate social group whose condition is conditioned by their social and living conditions (conditions of military service, relationships in the family) and individual and psychological characteristics (unstable psycho-emotional state, chronic state of distress, alcohol-, drug addiction) of its members - combatants.

Our research aims to argue for the need for the Center for Integrated Rehabilitation and assistance to combatants. The work of such a university-based institution will serve as a tool for rehabilitation and prevention of negative manifestations in the family environment of servicemen, unloading the work of establishments and institutions designed to assist combatants and their families. The theoretical and methodological basis of the teaching staff and students of specialties relevant to social rehabilitation can be realized through the practical work of the Center's rehabilitators.

Key words: military operations, difficult life circumstances, military personnel participating in hostilities, post-traumatic stress disorders, comprehensive rehabilitation, center of comprehensive rehabilitation and assistance to combatants.

\author{
УДК 378.22:78 \\ DOI https://doi.org/10.31392/NPU-nc.series5.2020.72-1.20
}

Bukhnieva O. A., Bankul L. D.

\title{
STRUCTURE OF PROFESSIONAL COMPETENCE OF FUTURE MUSIC ART TEACHERS
}

The article is devoted to the analysis of the structure of the leading pedagogical concept "competence" in the musicpedagogical field of education. There are considered formulation and understanding of competence in pedagogical activity from the point of view of modern domestic and foreign researchers. It is established that the structure of musical and pedagogical competence is carried by means of such categories as: socio-pedagogical, methodical, socio-psychological, creative, autopsychological, informative; an integrated ability of the individual to successfully perform performing activities; readiness for creative musical and pedagogical activity; personal quality (characteristic); the existence of relevant competences by a future music teacher (competence); ; a combination of knowledge, skills, norms, emotionally valuable attitude and reflection in music teaching; result-activity characteristic of education; educational results and so on.

The article describes the musical and pedagogical competence of future teachers of music art as one that has its structure. It is determined by the specificity of music education, but subject to the general laws of the theory of music and creative activity. The peculiarity of musical and creative activity is that it solves pedagogical tasks by means of musical art. The structure of musical and creative competence combines pedagogical, choirmaster, musicology, music-performing, research work. The work is based on the ability to independently summarize and systematize the acquired knowledge.

Essential components of music-pedagogical competence of future music teachers are determined by general and specific knowledge, skills, experience, personal values and The indispensable components of this competence are: knowledge, skills, experience, personal values and cultural-aesthetic attitude to activities in the arts field of education.

The article emphasizes that the peculiarity of music-pedagogical activity is the synthesis of pedagogical creativity (conditioned by the constant creative search of the teacher). Also it is emphasized on the artistic and musical creativity that is conditioned by the creative nature of the musical art itself. It is determined that artistic and pedagogical creativity should be considered as the main characteristic of the professional competence of the music art teacher. Its implementation is possible 
subject to the conditions of the presence of artistic and pedagogical task, reliance on basic laws and basic functions of creativity, artistic and pedagogical improvisation.

Key words: competence, competency-based approach, musical-pedagogical activity, knowledge, ability, creativity, pedagogical education, musical art, artistic and pedagogical creativity.

\section{(статтю подано мовою орихіналу)}

The 21 st century education continues to play an essential role in the social and economic development of society, especially in the process of its globalization and informatization. Competency-based approach is one of the new conceptual guidelines. It is tendency of development of the content of education in Ukraine and developed countries. In recent decades, well-known international organizations that are currently working in the field of education have been studying the problems associated with the competency-based education.

People's education and competences are becoming the most important values of a modern civilization and knowledgebased information society. These processes put the teacher's personality first, as a specialist in secondary and higher education. Their professional training and competence are important factors in the development of a modern information society. The level of teacher qualification and openness to innovations play an important role in society. It should inspire the younger generation to become such people who are ready to fulfill their potential. Those who can fulfill personal and professional tasks and become active participants in the development of world-class society.

The main task of the modern education system is to create the conditions for a quality education, to introduce a competency-based approach. This is the most important condition that works to improve the quality of education.

"Competency-based approach" is understood as the orientation of the educational process to the formation and development of key (basic, fundamental) and subject competences. In particular, it is meant to develop musical and pedagogical individual's competences. The result of such process will be the formation of a person's overall competence, which is a set of key competences, an integrated characteristic of the individual. Such a characteristic should be formed in the educative process. It must contain knowledge, skills, attitudes, experience and behavioral models of personality. Competence (from Latin. competens (competentis) - appropriate, corresponding), according to the dictionary of the foreign words, it means knowledgeability, awareness, authority [9].

The concept of competence has been introduced into the national scientific and pedagogical circulation under the influence of the European educational tradition. This tradition has been actively serving it for over a quarter of a century. But there is still no consensus among researchers about its content. Foreign scientists understand the competence as the ability of a person to apply their knowledge. Also it is understood as ability based on the experience or knowledge that a person has developed through practice or education. It is also understood as skills and abilities that a person can use in different situations and context, mastering new situations.

Compared to foreign scientists, most domestic researchers seek to broaden the content of the concept of competence. They want to include to this concept besides knowledge and skills in a particular field (as in most definitions of European scholars), various personal characteristics: values, motives, attitudes, etc.

For example, O. Pometun distinguishes the content of competence "in a special way structured sets of knowledge, skills, attitudes and attitudes acquired by the individual in the educative process. They allow it to determine, identify and solve problems, regardless of the context, that are specific to a particular field of activity" [7, p. 18]. An even broader approach to considering the meaning of the concept is demonstrated by N. Bibik. The scientist understands the competence as the set of physical and intellectual person's qualities. The qualities those are necessary for a person to independently and effectively solve different ccircumstances; to create better conditions for yourself in constructive interaction with other people. The expert believes that the competence represents educational outcomes that are achieved not only by means of educational content, but also by social interaction; both in interpersonal and institutional cultural contexts [1, p. 46].

The National Standard of General Education states that competence is "an acquired ability in the educational process of an individual's ability, which consists of knowledge, experience, values and attitudes that can be fully implemented in practice" [3].

Such national scientists and scientists from the near abroad investigated the point of competence: A. Antonova, L. Maslak, N. Bibik, S. Bondar, S. Vitvytska, N. Volkova, M. Golovan, O. Dubaseniuk, I. Zymnya, and I. Zyazyun, V. Kalney, O. Pometun, H. Selevko, N. Sydorchuk, Y. Tatur, A. Khutorskyi, F. Sharipov, S. Shyshov and others.

Scientists note that a competency-based approach is oriented to the formation of personal experience and valuebased evaluation of a specialist. Thus, I. Zymnya writes that professional competences are characterized by a fivecomponent structure and consist of knowledge, experience of application, values, regulation, readiness [4, p. 15]. In the works of H. Selevko the concept "competence is understood as an integral quality of a person, manifested in the general ability and readiness for activity. The activity is based on the knowledge and experience gained in the process of learning and socialization. It is oriented towards independent and successful participation in the activity" [8, p. 139]. V. Polishchuk emphasizes that the concept of competence is much broader and is not considered as a total of "knowledge - skills - experience". But it has a somewhat different meaning. It contains not only cognitive and operational-technological, but also individually-meaningful, creative and other components of personality. The modern specialist should be able to know himself and to teach future teachers to creatively introduce knowledge, to critically reflect obtained information [6, p. 12]. 
In the context of the future teacher's professional training, I. Ziaziun interprets competence as the ability to solve professional tasks of a particular class. It requires the availability of real knowledge, skills, experience $[5$, p. 14]. The same category is fundamental for understanding S. Bondar's competence: "competence is the ability of the individual to act" [2, p. 9].

Competency-based approach in music education is related to personally oriented and creative-activity approaches to studying. Inasmuch, it concerns the student's personality it can be realized and tested only in the course of performance by a particular student of a certain set of creative actions. It requires the transformation of the content of music education. It needs transformation from a model that exists, for all students, to the subjective and creative student's achievements.

The problems of professional competence of future music teachers and their structure are not sufficiently investigated.

The structure of competences in music education is as follows: key - those are supra-curricular competences, which are defined as the ability of a person to perform complex poly-subject, cultural and creative and artistic activities. It also allows to effectively solve the relevant problems; industry-wide - which are acquired by student during the music education studying; special - they are acquired by student during the study of musical art in high school classes.

The peculiarity of music-pedagogical activity of future teachers of music art is that it synthesizes pedagogical creativity (conditioned by constant creative search of the teacher connected with necessity of finding a solution for individually developing influence on the student, etc.) with artistic creativity, conditioned by the creative nature of the arts.

In this regard, the main characteristic of the professional competence of the future music teacher should be considered as artistic and pedagogical creativity. Its realization is possible under the following conditions: availability of musical artistic and pedagogical task; reliance on the basic laws and basic functions of musical creativity; musical and artistic and pedagogical improvisation.

Socio-cultural experience in applying to music-pedagogical education means professional competence and methodological equipment. The future teacher of music art must learn a certain amount of philosophical, aesthetic, social, psychological and pedagogical knowledge. The teacher must be able to apply them in his work.

The humanistic type of music-pedagogical competence of a future music teacher includes a personality-oriented aspect. This aspect is interpreted as a manifestation of the personality traits of the individual, professional activity and communication of the teacher. The personality-oriented professional-pedagogical competence of the future music art teacher structure indicators is humanistic orientation of the teacher's personality and his ability to be a teacher. This aspect includes psychological and pedagogical competence and developed pedagogical thinking. Also it includes the ability to solve emerging problems from the student's point of view; as an education in the field of music art, the ability to work with content and technology of music-creative training, giving them personal orientation; as an ability to substantiate and realize their own creative musical-pedagogical activity as a personalityoriented system (didactic, educational, methodical, performing); as a culture of professional behavior and creative self-development, the ability and willingness to self-regulate their own professional activities and processes of music-pedagogical interaction.

First of all, musical and pedagogical orientation of the future teacher's professional culture is manifested in the disclosure to the students the spiritual and moral content of life and art. It is manifested in the inner states, feelings and thoughts cultivation that correspond to universal human ideals. There is ability of a music teacher to create a spiritual atmosphere in the classroom. This ability helps students to correlate their worldview with the ideally valuable content of Ukrainian and world music art. The existence of such ability is an indicator of highly developed professionalism and competence of music education specialist.

The structure of professional and pedagogical competence of a future music teacher should include the following elements:

1) special pedagogical competence (teacher's awareness in the field of music-pedagogical science; possession of the art of transforming pedagogical science and aesthetic culture into a means of forming the musical-aesthetic culture of the student's personality);

2) methodological competence (any method of musical and pedagogical influence should become a method of creative musical and aesthetic students' activity. Such activities become a method of self-education and creative self-development of the student);

3) social and psychological competence (teacher's awareness in the field of multilevel artistic communication; the awareness of it as determinants of the process of achieving musical and pedagogical results in music arts classes);

4) creative and pedagogical competence (knowledge of the teacher of individual creative features of each student and ability to direct them in the creative direction);

5) autopsychological competence (teacher's awareness of ways of professional self-improvement (musical performance), professional qualities of personal activity and level of self-perfection of musical and pedagogical work).

The information component should serve as a fundamental basis for the future competence of a future music teacher. It includes specialist knowledge of the arts, its techniques, pedagogy and psychology. Their most important 
features are: complexity and consistency. These features require the teacher's ability to synthesize the studied aspects of art science; personal coloration at the level of sensitivity, manifested in the inspiration of knowledge, own view of the world. Professional knowledge is structured at different levels: methodological (knowledge of patterns of development of the general philosophical plan, conditionality of the goals of education); theoretical (laws, principles, rules of pedagogy and psychology, musical pedagogy, basic forms of activity); methodical (the level of construction of the music-pedagogical process); technological (level of solving practical educational problems in specific conditions).

Nowadays, there are several approaches to the issue of teacher competence in music education. The traditional approach in music education is to ensure that the student has as much theoretical knowledge and practical skills as possible. However, the level of education cannot be determined solely by the volume of these knowledge and skills. A competency-based approach in music education requires students to address issues of varying complexity, based on existing theoretical knowledge and practical skills. This approach not only appreciates one's own knowledge, but the ability to use it (for example, reading a variety of music literature, singing, and playing a musical instrument). The traditional approach seeks results that show what a new student studies at school. A competency-based approach makes it clear what the student has learned during his or her studying at school. Both approaches seek to develop certain creative qualities of personality in students. They seek to form a system of aesthetic and cultural artistic values. Thus, the solution of problems in the first case acts as a way of consolidating knowledge. According to the second case - the meaning of all educational and musical competence.

The competence of the future teacher of music art is not constant. It is a dynamic component in the structure of teacher's personality. Ideally, competence is improved as a teacher becomes professional. It improves when it comes to increasing knowledge, ability, and deeper understanding of the meaning of music and pedagogical work. Unfortunately, not all teachers reach higher levels of mastery of music-pedagogical activity. With age, they acquire habits and stereotypes, and even lose their habits. In particular in the field of performance, which is one of components of the musical-pedagogical music art teacher's competence.

The category of music-pedagogical competence can be defined as the ability to apply flexibly practical experience for successful activity in a given situation. The competencies form a "profile of a music teacher", which consists of general and professional competences.

The professional competence of a music teacher is the result of creative professional activity. It is an integrated indicator of the personality and activity of the teacher. Professionally competent teachers successfully complete the tasks of education and training. They achieve the desired results in the development of students' personalities. Such teachers are aware of the prospect of their professional development. They are open to continuing vocational training. Those teachers enrich the experience of the music and teaching profession through personal creative input.

Structural indicators of the professional competency-based approach of the future music teacher are manifested in the following aspects:

- highly professional knowledge in the field of music and performing arts teachers are large and deep. They represent systemic integrity, with high efficiency. Such arts are used to make decisions not only in typical conditions, but also in non-traditional situations. Some elements of knowledge are copyrighted, they are new;

- highly professional instrumental and performing teacher's skills are characterized by a skillful combination in performing actions of reproductive and creative order. It allows to achieve high performing results; the effectiveness of the practical implementation of individual enforcement actions is enhanced by means of copyright technology.

The professional-pedagogical activity of the future teacher of music arts includes a system of music-theoretical, conductor-choral and vocal-choral, musical-performing and methodical knowledge and skills. They are the basis of the general professional competence of a specialist. And they have moral and pedagogical orientation. Their existence (in combination with general cultural, psychological and pedagogical knowledge and skills, values and creative orientations, pedagogical and musical abilities, professionally significant qualities) is the most important condition. These orientations are the prerequisite for effective musical and educational activity.

\section{Used literature:}

1. Бібік Н. М. Компетентнісний підхід: рефлексивний аналіз застосування. Компетентнісний підхід у сучасній освіті: світовий досвід та українські перспективи: Бібліотека з освітньої політики / за заг. ред. О. В. Овчарук. Київ : «К. І. С.», 2004. C. $45-50$.

2. Боднар С. Компетентність особистості інтегрований компонент навчальних досягнень учнів. Біологія $i$ хімія в школі. 2003. № 2. С. 8 - 9 .

3. Державний стандарт початкової загальної освіти: http://mon.gov.ua/content (дата звернення 29.01.2020).

4. Зимняя И. А. Интегративный подход к оценке единой социально-профессиональной компетентности выпускников вузов. Выстее образование сегодня. 2008. № 5. С. 14-19.

5. Зязюн І. Філософія педагогічної якості в системі неперервної освіти. Вісник Житомирського державного університету імені Івана Франка. 2005. № 25. С. 13-18.

6. Поліщук В. П. Психологічний аналіз управлінської діяльності директора навчально-виховного закладу. Шлях освіти. 2012. № 7. С. 12.

7. Пометун О. І. Теорія та практика послідовної реалізації компетентісного підходу в досвіді зарубіжних країн. Компетентнісний підхід у сучасній освіті: світовий досвід та українські перспективи: Бібліотека з освітньої політики / за заг. ред. О. В. Овчарук. Київ : «К. І. С.», 2004. С. 15-24. 
8. Селевко Г. Компетентности и их классификация. Народное образование. 2004. №4. С. 138-143.

9. Словник іншомовних слів / уклад. Морозов С., Шкарапута Л. Київ : Наукова думка, 2000. 680 с.

\section{References:}

1. Bibik, N. M. (2004). Kompetentnisnyy pidkhid: refleksyvnyy analiz zastosuvannia [Competency Approach: Reflexive analysis of application]. Kompetentnisnyy pidkhid u suchasniy osviti: svitovyy dosvid ta ukrä̈nki perspektyvy: Biblioteka z osvitnoï polityky / Pid zah. red. O. V. Ovcharuk. Kyiv : «K.I.S.». S. 45-50. [in Ukranian].

2. Bodnar, S. (2003). Kompetentnist osobystosti intehrovanyy komponent navchalnykh dosiahnen uchniv [Personality competence is an integrated component of student learning achievement]. Biolohiia i khimiia v shkoli [Biology and chemistry at school]. No 2. S. 8 - 9. [in Ukranian].

3. Derzhavnyy̌ standart pochatkovoï zahalnoï osvity [State standard of elementary general education]. (h.d.). mon.gov.ua. Retrieved from http://mon.gov.ua/content [in Ukranian].

4. Zimnyaya, I. A. (2008). Integrativnyiy podhod k otsenke edinoy sotsialno-professionalnoy kompetentnosti vyipusknikov vuzov [An integrative approach to assessing the unified social and professional competence of university graduates]. Vyisshee obrazovanie segodnya [Higher education today]. \# 5. S. 14-19.

5. Ziaziun, I. (2005). Filosofiia pedahohichnoï yakosti v systemi neperervnoï osvity [Philosophy of pedagogical quality in the system of continuous education]. Visnyk Zhytomyrskoho derzhavnoho universytetu imeni Ivana Franka [Bulletin of Zhytomyr Ivan Franko State University]. № 25. S. 13-18.

6. Polishchuk, V.P. (2012). Psykholohichnyi analiz upravlinskoi diialnosti dyrektora navchalno-vykhovnoho zakladu [Psychological analysis of the managerial activity of the director of the educational institution.]. Shliakh osvity [The path of education]. № 7. S. 12.

7. Pometun, O. I. (2004). Teoriia ta praktyka poslidovnoï realizatsiï kompetentisnoho pidkhodu v dosvidi zarubizhnykh kraïn [Theory and practice of consistent implementation of a competent approach in the experience of foreign countries]. Kompetentnisnyy pidkhid u suchasniy osviti: svitovyy dosvid ta ukraïnski perspektyvy: Biblioteka z osvitnoï polityky / Pid zah. red. O. V. Ovcharuk. Kyiv : «K.I.S.», S. 15-24.

8. Selevko, G. (2004). Kompetentnosti i ih klassifikatsiya [Competencies and their classification]. Narodnoe obrazovanie [Public education]. \# 4. S. 138-143.

9. Morozov, S. Shkaraputa, L. (2000). Slovnyk inshomovnykh sliv [Dictionary of foreign words]. Kyiv : Naukova dumka, 680 s. [in Ukrainian].

\section{Бухнісва О. А., Банкул Л. Д. Структура професійної компетенції майбутніх вчителів музичного мистецтва}

Зроблено аналіз структури педагогічного поняття «компетентність» у музично-педагогічній галузі освіти. Розглянуто формулювання та розуміння компетентності у педагогічній діяльності з позииї сучасних вітчизняних та закордонних дослідників. Встановлено, що структура музично-педагогічної компетентності здійснюється за допомогою таких категорій, як: соціально-педагогічна, методична, соціально-психологічна, творча, аутопсихологічна, інформативна; інтегрована здатність особистості успішно здійснювати виконавську діяльність; готовність до творчоі музично-педагогічної діяльності; особистісна якість (властивість); володіння майбутнім вчителем музичного мистеичтва відповідною діяльністю (компетениією); поєднання знань, умінь і навичок, норм, емоційно-ціннісного ставлення та рефлексії у викладання музичного мистецттва; результативно-діяльнісна характеристика освіти; освітні результати тошо.

Схарактеризовано музично-педагогічну компетентність майбутніх вчителів музичного мистеитва як таку, щзо має свою структуру і визначається специфікою музичної освіти, але підпорядковану загальним закономірностям теорії музично-творчої діяльності. Специфіка музично-творчої діяльності полягає в тому, що вона вирішує педагогічні завдання засобами музичного мистеитва. Структура музично-творчої компетентності поєднує в собі педагогічну, хормейстерску, музикознавчу, музично-виконавську, дослідницьку роботу, засновану на вмінні самостійно узагальнювати і систематизувати отримані знання.

Неодмінними компонентами музично-педагогічної компетентності майбутніх вчителів музичного мистецтва визначаються загальні і специфічні знання, уміння, навички, досвід, особистісні иінності й культуро-естетичне ставлення до діяльності в мистеиькій освітній галузі.

У статті підкреслено, щзо особливістю музично-педагогічної діяльності є синтез педагогічної творчості (обумовленою постійним творчим пошуком вчителя) і художньо-музичної творчості (обумовленою творчою природою самого музичного мистеитва). Визначено, щчо основною характеристикою професійної компетенції вчителя музичного мистеитва слід вважати художньо-педагогічну творчість. Ї̈ реалізація можлива при дотриманні умов наявності художньо-педагогічного завдання, опори на базові закони і основні функиії творчості, художньо-педагогічної імпровізації.

Ключові слова: компетенція, компетентність, компетентнісний підхід, музично-педагогічна діяльність, знання, уміння, творчість, педагогічна освіта, музичне мистеитво, художньо-педагогічна творчість. 